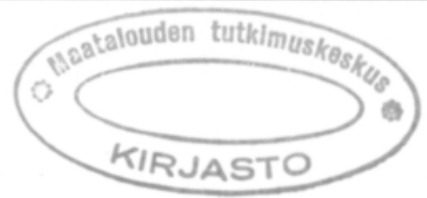

\title{
Sorption capacity of phosphate in mineral soils I Estimation of sorption capacity by means of sorption isotherms
}

\author{
RAINA NISKANEN \\ University of Helsinki, Department of Agricultural Chemistry, \\ SF-00710 Helsinki, Finland
}

\begin{abstract}
The sorption capacity of phosphate in seven soil samples (clay content $1-70 \%$, organic carbon content $0.8-10.7 \%$, soil pH 4.2-5.3, oxalate-extractable $\mathrm{Al} 11-222$ and $\mathrm{Fe} 11-202 \mathrm{mmol} / \mathrm{kg}$ soil) was studied by means of sorption isotherms. The soils were equilibrated, for two to seven days at +5 and $+20^{\circ} \mathrm{C}$, with solutions containing phosphate $0-10 \mathrm{mmol} / 1$ $(0-200 \mathrm{mmol} / \mathrm{kg}$ soil) at a constant ionic strength of 0.01 . Prolongation of the reaction time increased the sorption of phosphate only partially. The rise in temperature, from +5 to $+20^{\circ} \mathrm{C}$, increased the sorption from higher phosphate concentrations. At $+20^{\circ} \mathrm{C}$, the sorption curves of three soils showed a sorption maximum of 4,19 and $34 \mathrm{mmol} / \mathrm{kg}$ soil. The sorption data of six soils was in accordance with the Langmuir equation; the sorption maximum ranged from 15 to $119 \mathrm{mmol} / \mathrm{kg}$ soil, and were of the same magnitude as the maximums determined experimentally.
\end{abstract}

Index words: Langmuir equation, equilibrium constant, sorption maximum, temperature

\section{Introduction}

The sorption of phosphate reflects the ability of soil to retain anions of weak acids. This property is related to the content of active hydrous oxides of aluminium and iron in soil. The retention of phosphate is usually expressed by the amount or proportion of added phosphate sorbed under chosen conditions. The 'anion exchange capacity' of soil, determined according to the method developed by PIPER (1944), was previously used to measure the phosphate sorption capacity and to estimate the degree of saturation (e.g. Williams et al. 1958, Williams 1959, 1960, Williams and KNIGHT 1963). In determination of 'anion exchange capacity', soil is treated with $0.33 \mathrm{M}$ ammonium phosphate at $\mathrm{pH}$ 4 , and the sorbed phosphate is extracted with hot sodium hydroxide. It is acknowledged, however, that this method is rather drastic (Williams 1960) and may not give a realistic picture of the sorption capacity.

Nowadays phosphate sorption is often 
described by sorption isotherms, interpreted by means of adsorption equations. Earlier studies have applied only the Freundlich equation (e.g. Russell and Prescott 1916, TeräsvUORI 1954, KAILA 1959 a, 1959 b, 1963). The Langmuir equation is first applied to phosphate sorption by OLSEN and WATANABE (1957). The applicability of the Langmuir equation to describe phosphate sorption on Finnish soils has not been studied in detail.

The Freundlich equation was originally empirical, and lacked a theoretical foundation (BoHn et al. 1985). It implies that the energy of adsorption decreases logarithmically as the fraction of covered surface increases. The Freundlich equation can be derived theoretically by assuming that the decrease in adsorption energy occurring as the surface coverage increases is due to surface heterogeneity, but in most cases, the surface heterogeneity is unknown. The frequent good fit of adsorption data to this equation is influenced by the insensitivity of log-log plots and the flexibility afforded curve fitting by the two empirical constants. Further, the Freundlich equation has the limitation that it does not predict a maximum adsorption capacity.

Theoretically, the Langmuir equation can be used to describe the chemical equilibrium for the ligand exchange reactions of anions (AURA 1980). It is assumed that the adsorption energy does not vary with surface coverage. The Langmuir equation has the advantage that it defines a limit for adsorption on a given array of sites meeting the Langmuir model criteria. This apparent limit has been used to estimate the adsorption capacity of soils for, e.g. phosphate. The applicability of the Langmuir equation can be improved by using the equation for the two adsorption surfaces (Syers et al. 1973).

This study was performed in order to investigate preliminarily the availability of the Langmuir isotherms in estimating the phosphate sorption capacity in Finnish soils.

\section{Material and methods}

The material consisted of seven mineral soil samples; three surface soils and four deeper layer soils (Table 1), which were airdried and ground to pass a $2-\mathrm{mm}$ sieve. The particle-size distribution of the inorganic matter in the soil samples was determined by the pipette method (ELONEN 1971). The pH of the soil was measured in a soil- $0.01 \mathrm{M}$ $\mathrm{CaCl}_{2}$ suspension $(1: 2.5)$ (RyTi 1965). The organic carbon content of the soil samples was determined using a modified (GRAHAM 1948) Alten wet combustion method. Aluminium and iron were extracted (ratio 1:20 w/v, shaking time $2 \mathrm{~h}$ ) with $0.05 \mathrm{M}$ ammonium oxalate (pH 2.9) (NISKANEN 1989) and determined by atomic absorption spectrophotometry.

Isotherms for phosphate sorption were determined at +5 and $+20^{\circ} \mathrm{C}$. The soils were treated with solutions of different phosphate concentrations at a constant ionic strength of

Table :. Soil characteristics.

\begin{tabular}{|c|c|c|c|c|c|c|c|c|c|c|c|c|}
\hline \multirow{4}{*}{$\begin{array}{l}\text { Sample } \\
\text { No. }\end{array}$} & \multirow[t]{4}{*}{ Locality } & \multirow{4}{*}{$\begin{array}{l}\text { Depth, } \\
\mathrm{cm}\end{array}$} & \multirow{4}{*}{$\begin{array}{c}\mathrm{pH} \\
\left(\mathrm{CaCl}_{2}\right)\end{array}$} & \multirow{4}{*}{$\begin{array}{c}\text { Organic } \\
\text { C, } \%\end{array}$} & \multicolumn{5}{|c|}{ Particle-size distribution $(\mu \mathrm{m}) \%$} & \multirow{2}{*}{\multicolumn{3}{|c|}{$\begin{array}{c}\text { Oxalate- } \\
\text { extractable }\end{array}$}} \\
\hline & & & & & \multirow{3}{*}{$<2$} & \multirow{3}{*}{$2-20$} & \multirow{3}{*}{$20-60$} & \multirow{3}{*}{$60-200$} & \multirow{3}{*}{$>200$} & & & \\
\hline & & & & & & & & & & $\mathrm{Al}$ & $\mathrm{Fe}$ & \multirow[t]{2}{*}{$\mathrm{Fe} / \mathrm{Al}$} \\
\hline & & & & & & & & & & \multicolumn{2}{|c|}{$\mathrm{mmol} / \mathrm{kg}$} & \\
\hline 1 & Vaala & $20-40$ & 4.2 & 1.3 & 1 & 3 & 3 & 93 & 0 & 84 & 3 & 0.04 \\
\hline 2 & Viikki & $20-40$ & 4.6 & 0.8 & 2 & 1 & 7 & 35 & 56 & 91 & 39 & 0.42 \\
\hline 3 & Viikki & $0-20$ & 5.3 & 4.4 & 10 & 7 & 15 & 61 & 7 & 24 & 144 & 6.05 \\
\hline 4 & Imatra & $0-20$ & 5.1 & 3.6 & 13 & 20 & 27 & 31 & 9 & 160 & 52 & 0.33 \\
\hline 5 & Viikki & $20-40$ & 5.0 & 1.0 & 26 & 2 & 23 & 42 & 6 & 11 & 11 & 1.00 \\
\hline 6 & Viikki & $20-40$ & 4.8 & 2.6 & 47 & 30 & 18 & 5 & 0 & 68 & 202 & 2.99 \\
\hline 7 & Imatra & $0-20$ & 4.7 & 10.7 & 70 & 18 & 6 & 3 & 3 & 222 & 65 & 0.29 \\
\hline
\end{tabular}


0.01 adjusted with $\mathrm{KCl}$ as follows $(\mathrm{mmol} / \mathrm{l})$ :

$$
\begin{array}{lcccccccccc}
\mathrm{KH}_{2} \mathrm{PO}_{4} & 0 & 0.5 & 1.0 & 1.5 & 2.5 & 3.5 & 5.0 & 7.0 & 8.5 & 10.0 \\
\mathrm{KCl} & 10.0 & 9.5 & 9.0 & 8.5 & 7.5 & 6.5 & 5.0 & 3.0 & 1.5 & 0
\end{array}
$$

To inhibit microbial activity, the solutions contained $0.01 \% \mathrm{NaN}_{3}$.

Soil, $5 \mathrm{~g}$, was treated with $100 \mathrm{ml}$ solution (P-addition $0-200 \mathrm{mmol} / \mathrm{kg}$ soil) for $2-7$ days. The $\mathrm{pH}$ of suspensions was measured in the beginning of the experiment. The suspensions were then shaken for four hours, allowed to stand overnight; they were shaken during the reaction period daily for eight hours and left to stand overnight. At the end of the experiment, the suspensions were shaken for half an hour, the $\mathrm{pH}$ of the suspensions was measured and the supernatants were filtered. The phosphorus concentration of filtrates was determined by a modified molybdenum blue method (KAILA 1955) and by an ammonium vanadate method (JACKSON 1958). The amount of retained phosphate was calculated as the difference between the phosphate quantity present initially and that remaining in the supernatant. The experiment was carried out in duplicate.

\section{Results and discussion}

The sorbed amounts of phosphate and the corresponding phosphate concentrations in the equilibrium solution are presented in Fig. 1. As compared with doses used in the fertilization practice, the added amounts of phosphorus were very high; $1 \mathrm{mmol}$ of $\mathrm{P}$ per $\mathrm{kg}$ soil corresponds to $62 \mathrm{~kg}$ per hectare (bulk density of soil $1 \mathrm{~kg} / \mathrm{dm}^{3}$, the depth of plough

Table 2. Final $\mathrm{pH}$ of suspensions.

\begin{tabular}{cc}
\hline Soil & $\mathrm{pH}$ \\
\hline 1 & $4.9-5.2$ \\
2 & $5.3-5.7$ \\
3 & $5.4-5.9$ \\
4 & $5.5-5.7$ \\
5 & $5.5-5.6$ \\
6 & $4.9-5.2$ \\
7 & $4.7-5.1$ \\
\hline
\end{tabular}

layer $20 \mathrm{~cm}$ ). Such high amounts were used because the purpose was to saturate the phosphate sorption capacity of soils.

The $\mathrm{pH}$ of the suspensions did not change much during the sorption or with an increasing phosphate concentration. The final $\mathrm{pHs}$ of the suspensions are given in Table 2.

Prolongation of the reaction time did not significantly increase phosphate sorption on experimental soils at $+20^{\circ} \mathrm{C}$. Prolongation of the reaction time from three to seven days increased the phosphate sorption on soil 3 at $+5^{\circ} \mathrm{C}$ from lower phosphate concentrations.

The reaction time used in the experiment was rather long. It is often shorter in sorption studies, e.g. 18 (Bache and Williams 1971) or 24 hours (Olsen and Watanabe 1957, Singholka et al. 1975) for phosphate. According to HASEMAN et al. (1950), the most rapid sorption of phosphate takes place in as little as half an hour. RAJAN and WATKINSON (1976) considered a reaction time of three hours to be sufficient, because allophane samples studied retained during this time $80 \%$ of the phosphate sorbed during four days. According to Olsen and Watanabe (1957), phosphate sorbed during one day is $84-$ $100 \%$ of that sorbed during three days, and is exchangeable by ${ }^{32} \mathrm{P}$. After the rapid initial reaction, the sorption of phosphate can proceed slowly for weeks, but then not only surface adsorption is involved (HASEMAN et al. 1950, Olsen and Watanabe 1957, Juo and MADUAKOR 1974).

The rise in temperature from $+5^{\circ} \mathrm{C}$ to $+20^{\circ} \mathrm{C}$ increased the sorption of phosphate at higher concentrations, a finding in accordance with those of some earlier studies (Low and Black 1950, Muljadi et al. 1966, Kuo and Lotse 1974). This effect may be caused by the increased rate of phosphate sorption at higher temperature (HASEMAN et al. 1950, Gardner and Jones 1973). When the sorption time is long and the phosphate concentration is high, phosphate is adsorbed not only on surfaces but is also migrated into fine pores of hydrous oxides. The rate of migration, in 

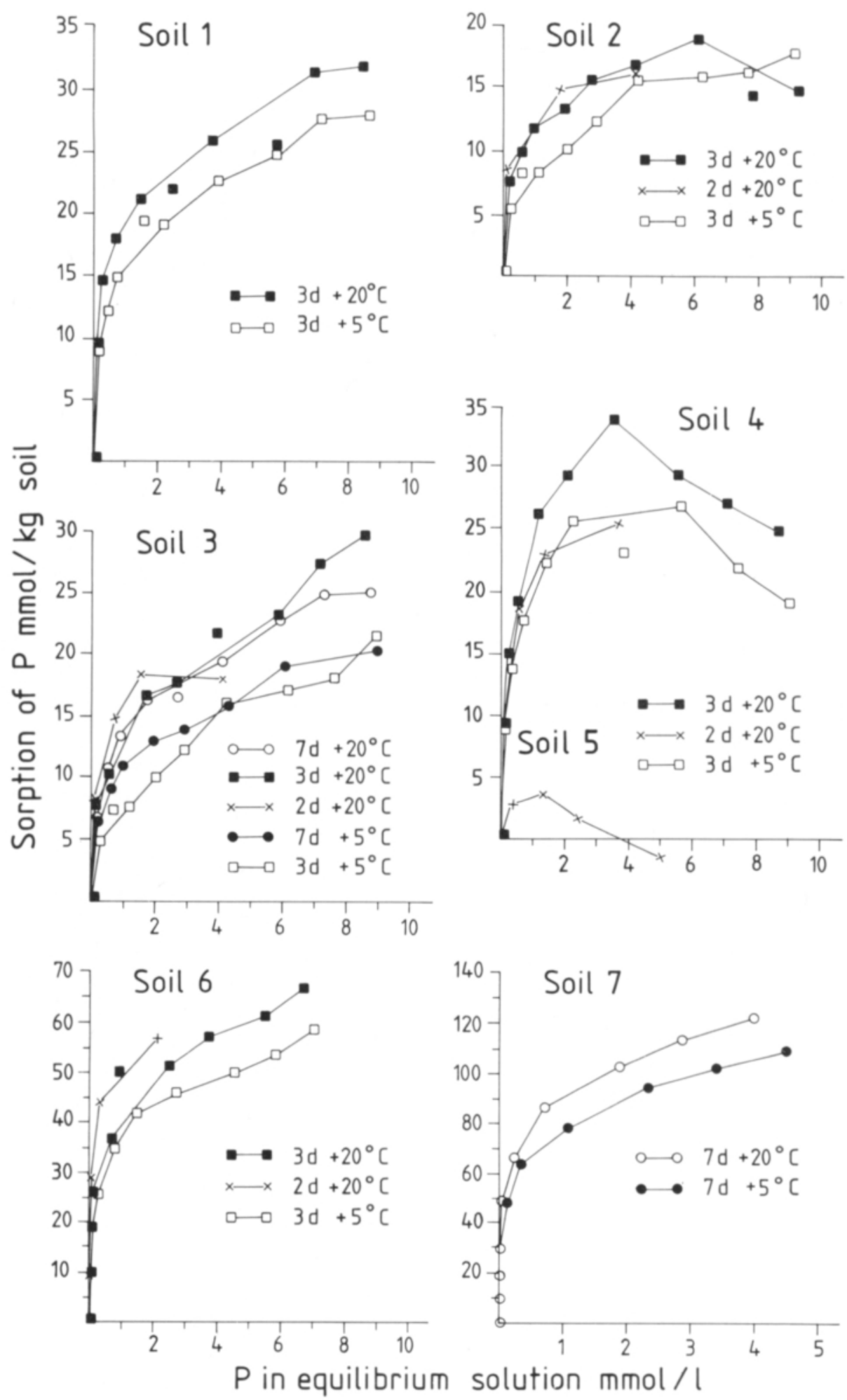

Fig. 1. Sorption of phosphate on experimental soils as a function of the phosphate concentration in the equilibrium solution. 
particular, increases with the rise in temperature.

At low phosphate concentrations, the soils adsorbed nearly all phosphate, nor did the sorption depend significantly on temperature. In the study of HartiKaINEN (1979), the effect of the rise in temperature on the phosphate concentration in the equilibrium solution in contact with acid soils was slightly positive, negative or nonexistent. The slight effect is due to the fact that the change of the standard enthalpy in the adsorption of phosphate is slight, and changes in entropy largely determine the equilibrium of phosphate adsorption in acid soils (AURA 1980).

Deeper layer soils 1 and 2 represented soils with a low clay content. The sorption of phosphorus was greater on soil 1 than on soil 2 (Fig. 1). The sorption curve of soil 1 at $20^{\circ} \mathrm{C}$ (3 d) flattened, when the sorption of $\mathrm{P}$ was about $30 \mathrm{mmol} / \mathrm{kg}$ soil. Soil 2 had a sorption maximum $\left(3 \mathrm{~d}, 20^{\circ} \mathrm{C}\right)$ of about $19 \mathrm{mmol} / \mathrm{kg}$ soil. The concentration of extractable aluminium was nearly equal in both soils, whereas the concentration of iron was greater in soil 2 (Table 1). On the basis of the sum of $\mathrm{Al}$ and $\mathrm{Fe}$, the sorption of $\mathrm{P}$ may have been greater in soil 2. The opposite result might have been caused by the lower $\mathrm{pH}$ of soil 1 (Table 1). The sorption of phosphate increases with a drop in $\mathrm{pH}$ (HINGSTON et al. 1972). In addition, soil 2 was coarser in texture than soil 1. The coarser texture means a smaller surface area and a smaller reacting surface.

Surface soils 3 and 4 had nearly equal pHs and clay and organic carbon contents, but soil 3 contained mainly extractable iron and soil 4 aluminium (Table 1). The sorption curve of soil $3\left(3 \mathrm{~d}, 20^{\circ} \mathrm{C}\right)$ showed no sorption maximum, but the curve still rose with the greatest addition of $\mathrm{P}$, the sorption being about 30 $\mathrm{mmol} / \mathrm{kg}$ soil (Fig. 1). Soil 4 had a sorption maximum of $34 \mathrm{mmol} / \mathrm{kg}$ soil; thereafter the sorption decreased rather steeply. Soil 5, which had low contents of aluminium and iron, showed a sorption curve course in equal to that of soil 4 ; the maximum sorption was $4 \mathrm{mmol} / \mathrm{kg}$ soil (Fig. 1).
Sorption curves which have a sorption maximum and thereafter a decreasing course have seldom been presented in the literature. In the study of RAJAN (1978), which concerned the sorption of sulphate on aluminium hydroxide, however, the sorption curve had a maximum and thereafter the sorption decreased as the concentration of sulphate in the reacting solution increased. The cause of the decreasing sorption is not clear, but it seems to be connected with a saturated sorption capacity. Decreasing sorption may perhaps result from the breaking of sorption surfaces. RAJAN (1978), however, found no noteworthy release of aluminium during sorption. Also in the present study, the release of $\mathrm{Al}$ and $\mathrm{Fe}$ did not seem to be very great. When experimental soils were extracted for four hours by $0.05 \mathrm{M}$ $\mathrm{KH}_{2} \mathrm{PO}_{4}$, the concentration of which was fivefold that of the strongest sorption solution, the amounts of iron and aluminium released were $40-70$ and $370-740 \mu \mathrm{mol} / \mathrm{kg}$ soil, respectively.

Soils 6 and 7 represented clay soils with nearly equal $\mathrm{pH}$, and the sum of extractable aluminium and iron was also about the same; however, soil 6 contained mainly iron and soil 7 aluminium (Table 1). The sorption curves of both soils still rose with the greatest additions of $\mathrm{P}$ (Fig. 1). With the addition of $200 \mathrm{mmol} / \mathrm{kg}$ soil, the sorption on soil 6 was $66 \mathrm{mmol} / \mathrm{kg}$ soil $\left(3 \mathrm{~d}, 20^{\circ} \mathrm{C}\right)$; on soil 7 it was $121 \mathrm{mmol} / \mathrm{kg}$ soil $\left(7 \mathrm{~d}, 20^{\circ} \mathrm{C}\right)$. The great difference in sorption between soils 6 and 7 may have been caused partially by the much higher content of organic carbon in soil 7 (Table 1). Soil organic matter inhibits crystallization of hydrous oxides and enhances their reactivity (Williams et al. 1958, SCHWERTMANN et al. 1968).

Langmuir equations and sorption maximums for experimental soils are given in Table 3. The Langmuir equation is based on the assumption that the energy of adsorption does not vary with the surface coverage, and may be written in linear form

$$
\frac{c}{x}=\frac{c}{x_{m}}+\frac{1}{k x_{m}}
$$


where $\mathrm{x}$ is the quantity of sorbed phosphate, $c$ the equilibrium phosphate concentration, $\mathrm{x}_{\mathrm{m}}$ the adsorption maximum and $\mathrm{k}$ a constant. A plot of $\mathrm{c} / \mathrm{x}$ against $\mathrm{c}$ should give a straight line of slope $1 / x_{m}$, from which an adsorption maximum can be calculated, and the equilibrium constant $\mathrm{k}$ relating to bonding energy can be calculated from the intercept. The plots are curved over wide concentration range (GUNARY 1970), which indicates that the bonding energy is not in fact constant and that there is no well-defined maximum. A possible reason for this is that sorbed phosphate migrates to sub-surface layers. The Langmuir equation is limited to the range for which experimental data are available. Even in systems where the energy of adsorption is not strictly constant, the Langmuir equation may still describe adsorption over a portion of the adsorption range, since the variation in the energy of adsorption should be slight if only one type of bonding mechanism predominates. The sorption data of experimental soils followed the Langmuir equation rather well when data obtained for a $\mathrm{P}$ addition of $0 \mathrm{mmol} / \mathrm{kg}$ soil were excluded (Table 3). It was not necessary to use the Langmuir equation for the two adsorption surfaces. Soil 5 is not included in Table 3 because the sorption capacity of this soil was low, and the sorption data were too limited for the Langmuir equation to be applied.

The Langmuir sorption maximum was the lowest in soil 2, which had the lowest organic carbon content (Table 3). The fact that the sorption maximum of soil 1 was of the same magnitude as that of soils 3 and 4, which had more than twice the metal content, may be explained by about the one unit lower $\mathrm{pH}$ of soil 1 as compared to the other soils. In deeper layer soil 1 , the saturation degree of sorption capacity may also be lower than in surface soils 3 and 4 . The sorption maximum of soil 7 was about double that of soil 6 . The calculated and experimentally detected sorption maximums were of the same order of magnitude. In most cases, the Langmuir sorption maximums as well as equilibrium constants increased with rising temperature (Table 3).

The Langmuir sorption maximum is an ap-

Table 3. Langmuir equations for $\mathbf{P}$ sorption on experimental soils, sorption maximums and equilibrium constants,

\begin{tabular}{|c|c|c|c|c|c|c|c|}
\hline $\begin{array}{l}\text { Soil } \\
\text { No. }\end{array}$ & $\begin{array}{l}\text { Temperature } \\
{ }^{\circ} \mathrm{C}\end{array}$ & $\begin{array}{l}\text { Sorption } \\
\text { time, d }\end{array}$ & Equation & $\mathrm{n}$ & $\mathrm{r}$ & $\begin{array}{l}\text { Maximum } \\
\text { sorption } \\
\mathrm{mmol} / \mathrm{kg} \text { soil }\end{array}$ & $\begin{array}{l}\text { Equilibrium } \\
\text { constant } \\
\mathrm{k} \times 10^{3}\end{array}$ \\
\hline 1 & $\begin{array}{r}5 \\
20\end{array}$ & $\begin{array}{l}3 \\
3\end{array}$ & $\begin{array}{l}y=20.04+0.0355 x \\
y=14.85+0.0323 x\end{array}$ & $\begin{array}{l}10 \\
10\end{array}$ & $\begin{array}{l}0.991 * * * \\
0.988^{* * * *}\end{array}$ & $\begin{array}{l}28.2 \\
31.0\end{array}$ & $\begin{array}{l}1.77 \\
2.18\end{array}$ \\
\hline 2 & $\begin{array}{r}5 \\
20 \\
20\end{array}$ & $\begin{array}{l}3 \\
2 \\
3\end{array}$ & $\begin{array}{l}y=48.44+0.0546 x \\
y=8.65+0.0613 x \\
y=4.51+0.0654 x\end{array}$ & $\begin{array}{r}10 \\
5 \\
9\end{array}$ & $\begin{array}{l}0.988^{* * *} \\
0.996^{* * *} \\
0.988^{* * *}\end{array}$ & $\begin{array}{l}18.3 \\
16.3 \\
15.3\end{array}$ & $\begin{array}{r}1.13 \\
7.09 \\
14.50\end{array}$ \\
\hline 3 & $\begin{array}{r}5 \\
5 \\
20 \\
20 \\
20\end{array}$ & $\begin{array}{l}3 \\
7 \\
2 \\
3 \\
7\end{array}$ & $\begin{array}{l}y=86.93+0.0418 x \\
y=45.66+0.0472 x \\
y=6.55+0.0539 x \\
y=44.23+0.0316 x \\
y=37.75+0.0368 x\end{array}$ & $\begin{array}{l}9 \\
9 \\
4 \\
9 \\
9\end{array}$ & $\begin{array}{l}0.975 * * * \\
0.992 * * * \\
0.999 * * * \\
0.979 * * * \\
0.992 * * *\end{array}$ & $\begin{array}{l}23.9 \\
21.2 \\
18.6 \\
31.7 \\
27.2\end{array}$ & $\begin{array}{l}0.48 \\
1.03 \\
8.24 \\
0.71 \\
0.98\end{array}$ \\
\hline 4 & $\begin{array}{r}5 \\
20 \\
20\end{array}$ & $\begin{array}{l}3 \\
2 \\
3\end{array}$ & $\begin{array}{l}\mathrm{y}=10.25+0.0356 \mathrm{x} \\
\mathrm{y}=6.77+0.0375 \mathrm{x} \\
\mathrm{y}=9.85+0.0278 \mathrm{x}\end{array}$ & $\begin{array}{l}6 \\
4 \\
6\end{array}$ & $\begin{array}{l}0.999^{* * *} \\
0.999^{* * *} \\
0.994^{* * *}\end{array}$ & $\begin{array}{l}28.1 \\
26.7 \\
36.0\end{array}$ & $\begin{array}{l}3.47 \\
5.54 \\
2.82\end{array}$ \\
\hline 6 & $\begin{array}{r}5 \\
20 \\
20\end{array}$ & $\begin{array}{l}3 \\
2 \\
3\end{array}$ & $\begin{array}{l}y=5.05+0.0177 x \\
y=1.18+0.0171 x \\
y=4.00+0.0155 x\end{array}$ & $\begin{array}{r}10 \\
4 \\
10\end{array}$ & $\begin{array}{l}0.994 * * * \\
0.9997 * * * \\
0.994 * * *\end{array}$ & $\begin{array}{l}56.5 \\
58.5 \\
64.5\end{array}$ & $\begin{array}{r}3.50 \\
14.47 \\
3.88\end{array}$ \\
\hline 7 & $\begin{array}{r}5 \\
20\end{array}$ & $\begin{array}{l}7 \\
7\end{array}$ & $\begin{array}{l}y=1.15+0.0094 x \\
y=0.97+0.0084 x\end{array}$ & $\begin{array}{r}10 \\
9\end{array}$ & $\begin{array}{l}0.996^{* * *} \\
0.997^{* * *}\end{array}$ & $\begin{array}{l}106.5 \\
119.3\end{array}$ & $\begin{array}{l}8.20 \\
8.60\end{array}$ \\
\hline
\end{tabular}


parent measure which cannot be realized in practice because surface properties are changed during sorption; e.g. the sorption of phosphate increases the negative charge of the sorption surface. In spite of this, the Langmuir sorption maximums can be used to compare the phosphate sorption properties of different soils.

\section{References}

AurA, E. 1980. Oxygen as an exchangeable ligand in soil. J. Scient. Agric. Soc. Finl. 52: 34-44.

BACHE, B.W. \& Williams, E.G. 1971. A phosphate sorption index for soils. J. Soil Sci. 22: 289-301.

Bohn, H., McNeal, B. \& O'Connor, G. 1985. Soil chemistry. 2nd ed. 341 p. New York.

Elonen, P. 1971. Particle-size analysis of soil. Acta Agr. Fenn. 122: 1-122.

GARDNER, B.R. \& Jones, P.J. 1973. Effects of temperature on phosphate sorption isotherms and phosphate desorption. Commun. Soil Sci. Pl. Anal. 4: 83-93.

Graham, E.R. 1948. Determination of soil organic matter by means of a photoelectric colorimeter. Soil Sci. 65: $181-183$.

Gunary, D. 1970. A new adsorption isotherm for phosphate in soil. J. Soil Sci. 21: 72-77.

Hartikainen, H. 1979. Phosphorus and its reactions in terrestrial soils and lake sediments. J. Scient. Agric. Soc. Finl. 51: 537-624.

Haseman, J.F., Brown, E.H. \& Whitt, C.D. 1950. Some reactions of phosphate with clays and hydrous oxides of iron and aluminium. Soil Sci. 70: 257-271.

Hingston, F.J., Posner, A.M. \& Quirk, J.P. 1972. Anion adsorption by goethite and gibbsite I. The role of the proton in determining adsorption envelopes. J. Soil Sci. 23: 177-192.

JACKsON, M.L. 1958. Soil chemical analysis. 498 p. London.

Juo, A.S.R. \& Maduakor, H.O. 1974. Phosphate sorption of some Nigerian soils and its effect on cation exchange capacity. Commun. Soil Sci. Pl. Anal. 5: $479-497$.

KAILA, A. 1955. Studies on the colorimetric determination of phosphorus in soil extracts. Acta Agr. Fenn. 83: $25-47$.

- 1959 a. Retention of phosphate by peat samples. J. Scient. Agric. Soc. Finl. 31: 215-225.

- $1959 \mathrm{~b}$. Effect of superphosphate on the retention of phosphorus by peat soil. J. Scient. Agric. Soc. Fini. 31: 259-267.

- 1963. Dependence of the phosphate sorption capacity on the aluminium and iron in Finnish soils. J. Scient. Agric. Soc. Finl. 35: 165-177.

Kuo, S. \& LotSE, E.G. 1974. Kinetics of phosphate adsorption and desorption by lake sediments. Soil Sci. Soc. Amer. Proc. 38: 50-54.

Low, P.F. \& BLACK, C.A. 1950. Reactions of phosphate with kaolinite. Soil Sci. 70: 273-290.
Muluadi, D., Posner, A.M. \& Quirk, J.P. 1966. The mechanism of phosphate adsorption by kaolinite, gibbsite and pseudoboehmite. Part III. The effect of temperature on adsorption. J. Soil Sci. 17: 238-247.

NisKanen, R. 1989. Extractable aluminium, iron and manganese in mineral soils. III Comparison of extraction methods. J. Agric. Sci. Finl. 61: 89-97.

Olsen, S.R. \& Watanabe, F.S. 1957. A method to determine a phosphorus adsorption maximum of soils as measured by the Langmuir isotherm. Soil Sci. Soc. Amer. Proc. 21: 144-149.

PIPER, C.S. 1944. Soil and plant analysis. 368 p. New York.

RAJAN, S.S.S. 1978. Sulfate adsorbed on hydrous alumina, ligands displaced, and changes in surface charge. Soil Sci. Soc. Amer. J. 42: 39-44.

- \& Watkinson, J.H. 1976. Adsorption of selenite and phosphate on an allophane clay. Soil Sci. Soc. Amer. J. 40: 51-54.

Russell, E.J. \& Prescott, J.A. 1916. The reaction between dilute acids and the phophorus compounds of the soil. J. Agr. Sci. 8: 65-110.

RYTI, R. 1965. On the determination of soil pH. J. Scient. Agric. Soc. Finl. 37: 51-60.

Schwertmann, U., Fischer, W.R. \& Papendorf, H. 1968. The influence of organic compounds on the formation of iron oxides. Trans. 9th Int. Cong. Soil Sci. 1: $645-655$.

Singholka, S., Ellis, J.H. \& Blevins, R.L. 1975. Adsorption and bonding energy indexes for phosphorus in four soils of northeast Thailand. Commun. Soil Sci. Pl. Anal. 6: 619-628.

Syers, J.K., Browman, M.G., Smillie, G.W. \& Corey, R.B. 1973. Phosphate sorption by soils evaluated by the Langmuir adsorption equation. Soil Sci. Soc. Amer. Proc. 37: 358-363.

TerĀsvuorı, A. 1954. Über die Anwendung saurer Extraktionslösungen zur Bestimmung des Phosphordüngerbedarfs des Bodens, nebst theoretischen Erörterungen über den Phosphorzustand des Bodens. Publ. Staatl. Landw. Versuchsw. Finnland Nr 141, 64 p. Helsinki.

Williams, E.G. 1959. Influences of parent material and drainage conditions on soil phosphorus relationships. Agrochimica 3: 279-309.

- 1960. Some aspects of phosphate retention and availability in soils. Trans. 7th Int. Cong. Soil Sci. 3: $604-611$. 
— \& KNIGHT, A.H. 1963. Evaluations of soil phosphate status by pot experiments, conventional extraction methods and labile phosphate values estimated with the aid of P-32. J. Sci. Food Agric. 8: 555-563.

-, ScotT, N.M. \& McDonald, M.J. 1958. Soil proper- ties and phosphate sorption. J. Sci. Food Agric. 9: $551-559$.

Ms received May 27, 1989

\section{SELOSTUS}

\section{Kivennäismaiden fosfaatin pidätyskapasiteetti I Pidätyskapasiteetin määrittäminen sorptioisotermien avulla}

\section{Raina Niskanen}

Maanviljelyskemian laitos, Helsingin yliopisto, 00710 Helsinki

Seitsemän maanăytteen (savespitoisuus $1-70 \%$, orgaanisen hiilen pitoisuus $0,8-10,7 \%, \mathrm{pH} 4,2-5,3$, oksalaattiuuttoinen $\mathrm{Al} 11-222$ ja Fe $11-202 \mathrm{mmol} / \mathrm{kg}$ maata) fosfaatin pidätyskapasiteettia tutkittiin sorptioisotermien avulla. Reaktioaika oli $2-7$ vuorokautta ja lämpötila $+5 \mathrm{ja}+20^{\circ} \mathrm{C}$. Reaktioliuokset sisälsivăt fosfaattia $0-10 \mathrm{mmol} / 1(0-200 \mathrm{mmol} / \mathrm{kg}$ maata $)$ ionivah- vuuden ollessa 0,01 . Kolmen maan sorptioisotermeissä $\left(+20^{\circ} \mathrm{C}\right)$ löydettiin kokeellisesti sorptiomaksimit, joiden suuruudet olivat 4,19 ja $34 \mathrm{mmol} / \mathrm{kg}$ maata. Kuuden maan sorptiotulokset noudattivat Langmuirin yhtälöä; lasketut sorptiomaksimit (15-119 mmol/ kg maata) olivat samaa suuruusluokkaa kuin kokeellisesti löydetyt. 